\title{
APLIKASI PUPUK KOMPOS DAN FREKUENSI PEMUPUKAN NPK DALAM MENINGKATKAN PRODUKSI BAWANG MERAH (Allium ascalonicum L) PADA TANAH GAMBUT
}

\author{
Compost Application and Frequency of NPK Apply to Improve Shallot (Allium \\ ascalonicum L) Production on Peatlands
}

\author{
Selvia Sutriana dan M. Nur \\ Fakultas Pertanian Universitas Islam Riau. Jl. Kaharuddin Nasution 113, Pekanbaru 28284 Riau \\ Telp. : 0761-72126 ext. 123, Fax : 0761-674681 \\ [Diterima: November 2018; Disetujui: Desember 2018]
}

\begin{abstract}
Peatlands is a very specific ecosystem with conditions that are always flooded, fragile, relatively infertile, able to absorb more water, and bad aeration. Riau has the largest peat land, which is $64 \%$ of the total peatlands area in Sumatra, but the development of shallot has not been intensively cultivated. So it must be dealt with seriously. The use of compost fertilizer and the frequency of NPK apply can improve the nature of these peatlands and increase crop production. The aim of study was to determine the interaction effect and the main application of compost and the frequency of NPK apply to increasing shallot production on peat soil. Research conducted at the Faculty of Agriculture Experimental Farm, Riau Islamic University during 6 month, i.e. form March - August 2018. Factorial Completely Randomized Research design, the first factor was 10, 20 and 30 tons/ha of corn compost, the second factor was NPK 16:16:16 fertilization frequency 1 and 2 fertilizing doses of 150, 300 and $450 \mathrm{~kg} / \mathrm{ha}$. Parameters observed were peat analysis, tuber number, tuber diameter, wet tuber weight per clump, dry tuber weight per clump and percentage of tuber shrinkage. The results showed that the interaction and main effects were significant for all observed parameters with the best treatment of compost is 30 tons/ha and 2 times the fertilizer dose of $150 \mathrm{~kg} / \mathrm{ha}$ per application (300 $\mathrm{kg} / \mathrm{ha})$.
\end{abstract}

Keywords: Shallot, Frequency, Compost, Fertilization, NPK, Production

\begin{abstract}
ABSTRAK
Lahan gambut merupakan suatu ekosistem yang sangat spesifik dengan kondisi yang selalu tergenang air, bersifat rapuh, relatif kurang subur, mampu menyerap air lebih banyak, dan aerasinya tidak baik. Provinsi Riau memiliki lahan gambut terluas yaitu 64\% dari luas total lahan gambut di Sumatera tetapi pengembangan tanaman bawang merah belum dibudidaya secara intensif. Hal ini merupakan permasalahan dalam budidaya bawang merah sehingga harus ditangani dengan serius. Penggunaan pupuk kompos dan frekuensi pemupukan NPK yang tepat dapat memperbaiki sifat lahan gambut tersebut dan meningkatkan produksi tanaman. Tujuan penelitian untuk mengetahui pengaruh interaksi dan utama aplikasi pupuk kompos dan frekuensi pemupukan NPK dalam meningkatkan produksi bawang merah pada tanah gambut. Penelitian dilaksanakan di Kebun Percobaan Fakultas Pertanian Universitas Islam Riau dari bulan Maret - Agustus 2018. Rancangan penelitian Acak Lengkap Faktorial, faktor pertama yaitu kompos serasah jagung 10, 20 dan 30 ton/ha, faktor kedua yaitu frekuensi pemupukan NPK 16:16:16 yiatu 1 dan 2 kali pemupukan dosis 150, 300 dan 450 $\mathrm{kg} / \mathrm{ha}$. Parameter yang diamati adalah analisis gambut, jumlah umbi, diameter umbi, berat umbi basah per rumpun, berat umbi kering per rumpun dan persentase susut umbi. Hasil penelitian menunjukkan bahwa pengaruh interaksi dan utama nyata terhadap semua parameter pengamatan dengan perlakuan terbaik kompos 30 ton/ha dan 2 kali pemupukan dosis $150 \mathrm{~kg} / \mathrm{ha}$ per satu kali pemberian $(300 \mathrm{~kg} / \mathrm{ha})$.
\end{abstract}

Kata Kunci: bawang merah, frekuensi, kompos, pemupukan, NPK, produksi 


\section{PENDAHULUAN}

Pengembangan tanaman hortikultura pada lahan gambut masih belum dimanfaatkan sebaik mungkin, padahal sangat penting dikembangkan mengingat tanaman bawang merah belum bisa digantikan oleh tanaman bumbu lainnya dan juga bisa menjadi pendapatan sampingan bagi petani dengan cara membudidayakan bawang merah di pekarangan rumah. Kandungan gizi bawang merah dalam $100 \mathrm{~g}$ : air $88 \mathrm{~g}$; energi 46 kkal; protein 1,5 g; lemak 0,3 g; karbohidrat 9,2 $\mathrm{g}$; abu $1 \mathrm{~g}$; kalsium $36 \mathrm{mg}$; fosfor $40 \mathrm{mg}$; besi $0,8 \mathrm{mg}$; tiamin $0,03 \mathrm{mg}$; dan vitamin C $2 \mathrm{mg}$ (Mahmud etal., 2009). Bawang merah juga dijadikan sumber antioksidan dan sebagai obat tradisional (kompres penurun panas, diabetes, penurun kadar gula, kolesterol darah, mencegah penebalan dan pengerasan pembuluh darah) karena kandungan senyawa allin dan allisin (Jaelani, 2007).

Permasalahan yang terjadi pada tanah gambut adalah kelebihan air hal ini berdampak pada kurangnya oksigen (O2) sehingga menghambat pertumbuhan akar, selain itu kelebihan bahan organik sama dengan kapasitas sangat tinggi dan membutuhkan kapur yang banyak, kekurangan tanah mineral sama dengan daya pegang akar rendah sehingga tanaman mudah rebah sehingga menyebabkan miskin hara dan pertumbuhan tanaman menjadi kerdil.

Salah satu alternatif untuk mengatasi masalah tanah gambut yaitu dengan pemberian pupuk kompos yang merupakan salah satu pupuk organik buatan manusia yang dibuat dari proses pembusukan/dekomposisi bahan-bahan organik. Kompos dapat meningkatkan kesuburan tanah, karena perannya yang sangat penting terhadap perbaikan sifat fisik, kimia dan biologi tanah (Setyorini et al., 2006; Syakir et al., 2009) dan juga dapat mengurangi kebutuhan pupuk kimia (an organik) karena kompos serasah jagung mengandung: C-organik 24,9\%, kadar abu 50,20\%, $\mathrm{N}$ total 1,33\%, C/N 18,67, P2O5 3,15\%, K2O 5,45\%, Ca 9,67\%, K 4,43\%, Mg 4,01\%, Na 2,58\% dan KTK 83,65 (Sutriana dan Raisa, 2017).

Penggunaan pupuk anorganik dengan dosis seimbang atau setengah dosis juga perlu diberikan pada tanah gambut untuk pertumbuhan dan perkembangan tanaman bawang merah. Pupuk NPK 16:16:16 merupakan salah satu pupuk anorganik majemuk yang mengandung unsur hara Nitrogen 16\%, Phospat 16\%, Kalium 16\%. Pupuk ini bersifat hidroskopis atau mudah larut sehingga mudah diserap oleh tanaman dan bersifat netral.

\section{METODE PENELITIAN}

Penelitian ini dilaksanakan di Kebun Percobaan Fakultas Pertanian Universitas Islam Riau Pekanbaru, selama 5 bulan, dimulai dari bulan Maret - Juli 2018. Bahan yang digunakan dalam penelitian adalah bibit bawang merah varietas Bima Brebes, pupuk kompos serasah jagung, pupuk NPK 16:16:16. Sedangkan alat yang digunakan dalam penelitian adalah cangkul, meteran, plat perlakuan, cat minyak, paku, timbangan analitik, handsprayer, gembor, kamera, dan alat-alat tulis.

Rancangan penelitian Acak Lengkap 2 faktorial. Faktor pertama adalah pupuk kompos (K) dengan 3 taraf perlakuan yaitu 10, 20 dan 30 ton/ha dan faktor kedua adalah Frekuensi pemupukan NPK 16:16:16 (F) dengan 6 taraf perlakuan yiatu 1 kali pemupukan dosis 150 , $300,450 \mathrm{~kg} / \mathrm{ha}$ dan 2 kali pemupukan dosis 150 , 300 dan $450 \mathrm{~kg} / \mathrm{ha}$. Masing-masing terdiri dari 3 ulangan dan 4 tanaman per plot dan 4 dijadikan sampel.

Pelaksanaan penelitian meliputi persiapan tempat penelitian, pembuatan kompos, persiapan Bahan Tanam, pemasangan Label, penanaman, pemberian pupuk kompos seminggu sebelum tanam dengan dosis K1: 40 g/polybag, K2: 80 g/polybag dan K3: 120 g/polybag (10, 20 dan 30 ton/ha) dan frekuensi pemupukan NPK 16:16:16 yaitu F1: 1 kali pemupukan dosis $150 \mathrm{~kg} / \mathrm{ha}$ diberikan pada saat tanam, F2: 1 kali pemupukan dosis $300 \mathrm{~kg} / \mathrm{ha}$ diberikan pada saat tanam, F3: 1 kali pemupukan dosis $450 \mathrm{~kg} / \mathrm{ha}$ diberikan pada saat tanam, F4: 2 kali pemupukan dosis $150 \mathrm{~kg} / \mathrm{ha}$, diberikan pada saat tanam dosis $75 \mathrm{~kg} / \mathrm{ha}$ dan 2 mst dosis $75 \mathrm{~kg} / \mathrm{ha}$, F5: 2 kali pemupukan dosis $150 \mathrm{~kg} / \mathrm{ha}$, diberikan pada saat tanam dan $150 \mathrm{~kg} / \mathrm{ha}$ diberikan $2 \mathrm{mst}$, F6: 2 kali pemupukan dosis $450 \mathrm{~kg} / \mathrm{ha}$, diberikan pada saat tanam dosis $225 \mathrm{~kg} / \mathrm{ha}$ dan 2 mst dosis $225 \mathrm{~kg} / \mathrm{ha}$. Pemeliharaan (penyiraman, penyiangan dan pengendalian hama penyakit) dan panen dengan kriteria daun mulai menguning dan daun mulai rebah $60-70 \%$, 
pangkal daun menipis.Panen dilakukan dengan mencabut seluruh tanaman dengan hati-hati supaya tidak ada umbi yang tertinggal atau lecet.

Parameter yang diamati adalah analisis gambut, jumlah umbi, diameter umbi, berat umbi basah per rumpun, berat umbi kering per rumpun dan persentase susut umbi.

\section{HASIL DAN PEMBAHASAN}

\section{Analisis Gambut}

Tabel 1. Hasil Analisis Kimia Tanah

\begin{tabular}{lcc}
\hline \multicolumn{1}{c}{ Sifat Kimia } & $\begin{array}{c}\text { Sebelum } \\
\text { Perlakuan }\end{array}$ & $\begin{array}{c}\text { Sesudah } \\
\text { Perlakuan }\end{array}$ \\
\hline $\mathrm{pH}\left(\mathrm{H}_{2} \mathrm{O}\right)$ & 3,89 & 4,40 \\
$\mathrm{C}-$ Organik $(\%)$ & 42,85 & 21,14 \\
$\mathrm{~N}-\mathrm{Total}(\%)$ & 0,30 & 0,47 \\
$\mathrm{P}_{2} \mathrm{O}_{5}(\mathrm{mg} / 100 \mathrm{~g})$ & 42,42 & 18,45 \\
$\mathrm{KTK}(\mathrm{me} / 100 \mathrm{~g})$ & 50,68 & 67,31 \\
\hline
\end{tabular}

Tanah gambut yang digunakan dalam penelitian ini sebelumnya belum pernah digunakan. Gambut ini hanya ditumbuhi ilalang dan semak. Kondisi lapisan bawah tanah gambut umumnya lebih masam dibandingkan lapisan atas. Pada lahan gambut bukaan baru yang memiliki tingkat kematangan fibrik atau mendekati hemik untuk budidaya bawang, harus mewaspadai keberadaanm rayap. Pengalaman menunjukkan bahwa gambut bukaan baru yang terdapat populasi rayap, maka rayap dapat menyerang umbi bawang merah (Firmansyah, 2014)

Hasil analisis pada Tabel 1 menunjukkan bahwa $\mathrm{pH} \mathrm{H}_{2} \mathrm{O}$ sebelum diberi perlakuan pupuk kompos dan NPK menunjukkan bahwa gambut tergolong masam yaitu 3,89 . Hal ini cukup mengkhawatirkan karena dapat menghambat perkembangan akar sehingga menyebabkan terganggunya pertumbuhan dan produksi bawang merah bahkan mungkin mati karena keracunan. Setelah diberikan perlakuan, hasil yang diperoleh menunjukkan bahwa ada peningkatan tidak terlalu signifikan yaitu 4,40 yang masih tergolong masam tetapi cukup untuk perkembangan tanaman bawang merah.

Kompos banyak mengandung senyawa organik sederhana dalam bentuk gugus karboksil dan fenolik yang mampu mengikat $\mathrm{Al}$ dan $\mathrm{Fe}$ membuka ikatan kompleks sehingga tidak mampu menyumbang kanion $\mathrm{H}+$ kedalam tanah yang berarti kondisi ini menurunkan kemasaman (Maryati et al., 2014). Menurut
Bancin et al., (2016) menyatakan bahwa meningkatnya $\mathrm{pH}$ tanah menentukan mudah tidaknya unsur-unsur hara baik makro maupun mikro diserap oleh tanaman sehingga berpengaruh terhadap pertumbuhan dan produksi tanaman bawang merah.

Menurut Hardjowigno (2003) pada tanahtanah masam unsur mikro juga mudah larut, sehingga ditemukan unsur mikro yang terlalu banyak dapat menjadi racun bagi tanaman bawang merah. Sedangkan menurut Firmansyah (2014) menyatakan bahwa cekaman kemasaman tersebut diindikasikan dengan tidak maksimalnya pertumbuhan perakaran dan daun, serta produksi umbi yang jauh dari potensi produksinya.Kondisi ini dimasa yang akan datang harus diperbaiki dengan cara melakukan penaburan dan pencampuran kompos lebih merata dengan ketebalan hingga $25 \mathrm{~cm}$ dimana merupakan zona dengan ketebalan aman bagi pertumbuhan dan perakaranbawang merah. Dengan demikian bawang merah terhindar dari media yang sangat masam, sehinggabebas dari cekaman keracunan.

Kandungan C-Organik gambut mengalami penurunan sebesar $50,66 \%$ setelah diberi perlakuan kompos dan NPK. Hal ini diduga terjadi karena adanya peningkatan aktifitas dekomposisi oleh mikroorganisme tanah akibat pemberian kompos.Nilai $\mathrm{C} / \mathrm{N}$ rasio tanah gambut setelah perlakuan kompos berkisar 9-14 \%. Hal ini menunjukkan bahwa proses dekomposisi bahan organik sudah diuraikan sempurna (Aryanti et al., 2016).

Kandungan N-Total setelah diberi perlakuan kompos dan NPK meningkat sebesar $36,17 \%$. Kandungan N-total setelah perlakuan masih dalam kategori sedang. Kandungan N berkorelasi dengan tingkat dekomposisi, semakin tinggi dekomposisi maka nilai $\mathrm{N}$ juga akan semakin tinggi atau sebaliknya (Masganti et al., 2014).Nitrogen pada tanah gambut sulit tersedia bagi tanaman di tanah gambut karena dipakai oleh jasad renik dalam dekomposisi bahan organik yang terkandung dalam gambut (Ariyanti, dkk, 2016). Rajagukguk (2001) menyatakanbahwa kadar nitrogen total pada tanah gambut umumnya tinggi tetapi $\mathrm{N}$ hanya akan tersedia setelah drainase dan mineralisasi, lain halnya pada tanah gambut yang dalam kondisi tergenang, nitrogen yang ada akan digunakan untuk dekomposisi bahan gambut 
oleh mikroorganisme sehingga tidak tersedia bagi tanaman.

Kandungan P-total mengalami penurunan sebesar 56,50\% setelah pemberian kompos dan NPK. Penurunan kandungan $P$ setelah perlakuan dapat meningkatkan fiksasi $\mathrm{P}$ oleh kation asam di dalam tanah gambut sehingga dapat menghambat ketersedian $\mathrm{P}$ dalam tanah.Rendahnya $\mathrm{P}$ pada tanah gambut diduga lahan gambut merupakan hasil akumulasi bahan organik yang belum terdekomposisisecara sempurna dan menyebabkan lahan gambut miskin unsur haraP, maka dari itu unsur haraPpada tanah gambut sangat diperlukan terhadap perubahan kesuburan tanah (Agus \& Subiksa, 2008).

KTK tanah setelah pemberian kompos dan NPK mengalami peningkatan sebesar $24,70 \%$. Hal ini disebabkan oleh penambahan bahan organik pada tanah gambut dapat meningkatkan kapasitas tukar kation (KTK) tanah karena memiliki daya jerap kation yang lebih besar.

\section{Jumlah Umbi Per Rumpun}

Hasil pengamatan terhadap parameter pengamatan jumlah umbi per rumpun bawang merah pada tanah gambut setelah dianalisis ragam menunjukkan bahwa pengaruh interaksi dan utama aplikasi pupuk kompos dan frekuensi pemupukan NPK nyata.Rerata jumlah umbi per rumpun dapat dilihat pada Tabel 2 .

Data pada Tabel 2 dapat dilihat bahwa aplikasi kompos yang dikombinasikan dengan frekuensi pemupukan memberikan pengaruh nyata terhadap jumlah umbi per rumpun.Jumlah umbi yang dihasilkan masih termasuk dalam deksripsi bawang merah yaitu 7-12 umbi per rumpunnya.Jumlah umbi terbanyak pada pemberian kompos $20-30$ ton/ha yang dikombinasikan dengan frekuensi pemupukan 1 kali dengan dosis $450 \mathrm{~kg} / \mathrm{ha}$ diberikan pada saat tanam atau frekuensi pemupukan 2 kali dengan dosis $300-450 \mathrm{~kg} / \mathrm{ha}$ yang diberikan pada saat tanam dan 2 minggu setelah tanam.

Pemberian pupuk pada frekuensi 2 kali berada pada kondisi jumlah haratersediayang dapat diserapdan dapat berperan membantu meningkatkan proses penyerapan hara dari dalam tanah secarakontinyu sehingga dapat berperan membantu meningkatkan proses penyerapan hara dari dalam tanah secara maksimalyang mendukung masa pertumbuhan bagian vegetatif tanaman hingga masa pembentukan umbi bawang merah lebih baik.

Umbi bawang merah merupakan pangkal daun yang berubah bentuk dan fungsi menjadi umbi lapis. Umbi tersebut dapat membentuk tunas baru yang kemudian tumbuh besar dan dewasa membentuk umbi kembali. Karena sifat pertumbuhannya yang demikian maka dari satu umbi membentuk rumpun tanaman yang berasal dari peranakkan umbi (Rahayu dan Berlian, 2002). Jumlah umbi berkorelasi dengan jumlah anakan. Semakin banyak jumlah anakan maka kemungkinan besar jumlah umbi akan banyak pula.

Hasil penelitian menunjukkan bahwa untuk memperbanyak jumlah umbi bawang merah membutuhkan dosis kompos yang sedang sampai tinggi dan pemupukan NPK dapat diberikan 1 atau 2 kali asalkan dengan dosis 300 - $400 \mathrm{~kg} / \mathrm{ha}$.Artinya dengan pemberian pupuk organik yang tinggi belum mampu mengurangi penggunaan pupuk anorganik pada tanah gambut yang pHnya masih rendah, sehingga perlu penambahan amelioran atau pupuk organik untuk meningkatkan pertumbuhan dan

Tabel 2. Rerata jumlah umbi per rumpun bawang merah dengan perlakuan kompos serasah jagung dan frekuensi pemupukan NPK pada tanah gambut (hst)

\begin{tabular}{cccccccc}
\hline \multirow{2}{*}{$\begin{array}{c}\text { Kompos } \\
\text { (ton/ha) }\end{array}$} & $1 / 150$ & $1 / 300$ & $1 / 450$ & $2 / 150$ & $2 / 300$ & $2 / 450$ & Rerata \\
\cline { 2 - 6 } & $6,00 \mathrm{e}$ & $7,41 \mathrm{~b}-\mathrm{e}$ & $6,91 \mathrm{c}-\mathrm{e}$ & $7,50 \mathrm{~b}-\mathrm{e}$ & $9,00 \mathrm{ab}$ & $8,00 \mathrm{~b}-\mathrm{d}$ & $7,47 \mathrm{c}$ \\
10 & $6,50 \mathrm{de}$ & $7,91 \mathrm{~b}-\mathrm{d}$ & $10,58 \mathrm{a}$ & $7,00 \mathrm{c}-\mathrm{e}$ & $8,25 \mathrm{~b}-\mathrm{d}$ & $8,66 \mathrm{bc}$ & $8,15 \mathrm{~b}$ \\
30 & $7,33 \mathrm{~b}-\mathrm{e}$ & $8,58 \mathrm{bc}$ & $9,00 \mathrm{ab}$ & $7,41 \mathrm{~b}-\mathrm{e}$ & $10,58 \mathrm{a}$ & $9,00 \mathrm{ab}$ & $8,65 \mathrm{a}$ \\
Rerata & $6,61 \mathrm{~d}$ & $7,97 \mathrm{bc}$ & $8,83 \mathrm{a}$ & $7,30 \mathrm{~cd}$ & $9,27 \mathrm{a}$ & $8,55 \mathrm{ab}$ & \\
\hline
\end{tabular}

KK : $7,35 \% \quad$ BNJ KF : $1,82 \quad$ BNJ K : $0,48 \quad$ BNJ F : 0,84

Angka-angka pada baris dan kolom yang diikuti huruf kecil yang sama menunjukan tidak berbeda nyata menurut uji lanjut BNJ pada taraf $5 \%$. 
Aplikasi Pupuk Kompos dan Frekuensi Pemupukan NPK dalam Meningkatkan Produksi Bawang Merah (Allium ascalonicum L) pada Tanah Gambut

produksi bawang merah.

Puspitasari et al.(2013) menyatakan bahwa dengan penambahan kompos maka kapasitas jerapan dan kekuatan jerapan tanah gambut akan meningkatkan nilai kejenuhan basa, sehingga ketersediaan unsur hara didalam tanah akan meningkat seperti N, P dan K.

Lingga (2001) menyatakan bahwa nitrogen dalam jumlah yang cukup,berperan dalam mempercepat pertumbuhan tanaman secara keseluruhan, khususnya batang dan daun.Selain itu, Yuliarti (2007) menambahkan yang lebih banyak karena faktor anakan berpengaruh terhadap jumlah umbi.

\section{Diameter Umbi}

Hasil pengamatan terhadap parameter pengamatan diameter umbi bawang merah pada tanah gambut setelah dianalisis ragam menunjukkan bahwa pengaruh interaksi dan utama aplikasi pupuk kompos dan frekuensi pemupukan NPK nyata.Rerata Diameter umbi dapat dilihat pada Tabel 3 .

Tabel 3. Rerata diameter umbi bawang merah dengan perlakuan kompos serasah jagung dan frekuensi pemupukan NPK pada tanah gambut $(\mathrm{cm})$

\begin{tabular}{|c|c|c|c|c|c|c|c|}
\hline \multirow{2}{*}{$\begin{array}{l}\text { Kompos } \\
\text { (ton/ha) }\end{array}$} & \multicolumn{6}{|c|}{ Frekuensi Pemupukan NPK (kali/kg/ha) } & \multirow[t]{2}{*}{ Rerata } \\
\hline & $1 / 150$ & $1 / 300$ & $1 / 450$ & $2 / 150$ & $2 / 300$ & $2 / 450$ & \\
\hline 10 & $1,73 \mathrm{f}$ & 2,10 ef & 2,06 ef & $1,83 \mathrm{f}$ & $2,23 \mathrm{c}-\mathrm{f}$ & $2,23 \mathrm{c}-\mathrm{f}$ & $2,03 \mathrm{c}$ \\
\hline 20 & $1,66 \mathrm{f}$ & $2,23 \mathrm{c}-\mathrm{f}$ & $2,20 \mathrm{~d}-\mathrm{f}$ & $1,86 \mathrm{f}$ & $2,80 \mathrm{bc}$ & $2,46 \mathrm{~b}-\mathrm{e}$ & $2,20 \mathrm{~b}$ \\
\hline 30 & $1,83 \mathrm{f}$ & $2,70 \mathrm{~b}-\mathrm{d}$ & $2,86 \mathrm{ab}$ & $1,83 \mathrm{f}$ & $3,40 \mathrm{a}$ & $2,80 \mathrm{bc}$ & $2,57 \mathrm{a}$ \\
\hline Rerata & $1,74 \mathrm{c}$ & $2,34 \mathrm{~b}$ & $2,37 \mathrm{~b}$ & $1,84 \mathrm{c}$ & $2,81 \mathrm{a}$ & $2,50 \mathrm{~b}$ & \\
\hline KK : 8,30\% & $\mathrm{BI}$ & $\mathrm{KF}: 0,57$ & BNJ & 0,15 & BNJF: & & \\
\hline
\end{tabular}

bahwa nitrogen berfungsi sebagai bahan sintesis klorofil, protein dan asam amino. Banyaknyaunsur harayang diserap oleh tanaman dari tanah berpengaruhdalam proses pembentukan daun karena pembentukan sel-sel baru dalam suatu tanaman sangat erat hubungannya denganhara yang ada dalam tanaman. Proses pembentukan daun tidak terlepas dari peranan unsur hara seperti nitrogen dan fosforyang terdapat pada medium tanah dan tersedia bagi tanaman. Secara umum tanaman kekurangan unsurhara akan menghambat pembentukan daun yang baru. Jumin (2012) menyatakan bahwa tanaman yang tidak mendapat tambahan nitrogen akan tumbuh kerdil serta daun yang terbentuk lebih kecil, tipis dan jumlahnya akan sedikit sedangkan tanaman yang mendapatkan unsur nitrogenyang cukup maka daun yang terbentuk akan lebih banyak dan lebar.

Menurut Elisabeth (2013), Kandungan unsur $\mathrm{N}$ yang tinggi membuat tanaman lebih hijau sehingga proses fotosintesis dapat berjalan sempurna yang berpengaruh terhadap kualitas dan kuantitas hasil akhir panen dengan kandungan unsur $\mathrm{N}$ yang lebih banyak maka akan merangsang tumbuhnya anakan sehingga akan diperoleh hasil panen dengan jumlah umbi
Data pada Tabel 3 dapat dilihat bahwa pemberian kompos serasah jagung sebanyak 30 ton/ha yang dikombinasikan dengan frekuensi pemupukan 1 kali atau 2 kali dosis pupuk NPK sebanyak $300-450 \mathrm{~kg} / \mathrm{ha}$ telah mampu meningkatkan diameter umbi bawang merah sebesar 3,40 cm dan 2,86 cm. Meskipun jika dilihat dari deskripsi bawang merah ini masih tergolong rendah - sedang. Hal ini dikarenakan $\mathrm{pH}$ tanah gambut yang masih tergolong rendah dan perlu penambahan amelioran dan pupuk organik cair untuk pembesaran umbi. Selanjutnya didalam pemeliharaan juga perlu adanya penggemburan tanah, sedangkan waktu pelaksanaan penelitian ini tidak dilakukan, sehingga menghambat pembesaran umbi bawang merah.

Menurut Putrasamedja dan Soedomo (2007), selain pemupukan, lingkungan, dan pemeliharaan besar umbi juga dipengaruhi oleh faktor genetik. Jika berbagai varietas ditanam dilahan yang sama, maka besar umbi tiap varietasjuga berbeda.

Dalam perkembangan buah, unsur yang paling penting adalah unsur $\mathrm{N}, \mathrm{P}$ dan $\mathrm{K}$. Menurut Sanchez (1992), tanaman umbiumbian merupakan penyerap fosfor yang tinggi. Fosfor sangat penting untuk pembentukan dan 
perkembangan umbi.Unsur kalium juga sangat penting bagi tanaman bawang. Kalium berperan dalam proses metabolisme, absorbsi hara, transpirasi, translokasi karbohidrat, pengaktif dari sejumlah besar enzim yang penting untuk fotosintesis dan respirasi (Salisbury dan Ross, 1995). Ketersediaan unsur hara (N, P, K) yang terkandung dalam kompos, memberikan respon yang positif terhadap pertumbuhan umbi, yang akan diserap dan ditranslokasikan ke daun untuk diasimilasikan dalam proses fotosintesis. Salah satu hasil fotosintesis ini adalah fruktan, dimana fruktan sangat diperlukan untuk pembentukan umbi (Yetti dan Elita, 2008).Tanaman Liliaceae menyimpan fruktan di dalam umbi (Salisbury dan Ross, 1995).

\section{Berat Umbi Basah Per Rumpun}

Hasil pengamatan terhadap parameter pengamatan berat umbi basah per rumpun bawang merah pada tanah gambut setelah dianalisis ragam menunjukkan bahwa pengaruh interaksi dan utama aplikasi pupuk kompos dan frekuensi pemupukan NPK nyata.Rerata Berat umbi basah per rumpun dapat dilihat pada Tabel 4. merupakan penyerap fosfor yang tinggi. Fosfor sangat penting untuk pembentukan dan perkembangan umbi.Unsur kalium juga sangat penting bagi tanaman bawang. Kalium berperan dalam proses metabolisme, absorbsi hara, transpirasi, translokasi karbohidrat, pengaktif dari sejumlah besar enzim yang penting untuk fotosintesis dan respirasi (Salisbury dan Ross, 1995).

Berat segar tanaman tergantung kadar air dalam jaringan dimana proses fisiologi yang berlangsung pada tumbuhan banyak berkaitan dengan air atau bahan-bahan yang terlarut dalam air. Hal ini sejalan dengan pendapat Jumin (2012) bahwa berat segar tanaman mencerminkan komposisi hara di jaringan tanaman dengan mengikut sertakan airnya. Air akan membentuk ikatan hidrogen dengan bahan organik seperti protein dan karbohidrat. Penambahan pupuk organik dapat meningkatkan kandungan hara yang ada didalam tanah, sehingga dapat digunakan untuk pertumbuhan tanaman. Menurut Sutanto (2002) pupuk organik merupakan bahan pembenah tanah yang lebih baik daripada bahan pembenah buatan, walaupun pada umumnya pupuk

Tabel 4. Rerata berat umbi basah per rumpun bawang merah dengan perlakuan kompos serasah jagung dan frekuensi pemupukan NPK pada tanah gambut $(\mathrm{g})$

\begin{tabular}{|c|c|c|c|c|c|c|c|}
\hline \multirow{2}{*}{$\begin{array}{l}\text { Kompos } \\
\text { (ton/ha) }\end{array}$} & \multicolumn{6}{|c|}{ Frekuensi Pemupukan NPK (kali/kg/ha) } & \multirow[t]{2}{*}{ Rerata } \\
\hline & $1 / 150$ & $1 / 300$ & $1 / 450$ & $2 / 150$ & $2 / 300$ & $2 / 450$ & \\
\hline 10 & $18,44 \mathrm{fg}$ & $22,36 \mathrm{ef}$ & $21,09 \mathrm{e}-\mathrm{g}$ & $18,95 \mathrm{fg}$ & $23,60 \mathrm{c}-\mathrm{f}$ & $22,40 \mathrm{ef}$ & $21,14 \mathrm{c}$ \\
\hline 20 & $16,80 \mathrm{~g}$ & $23,39 \mathrm{c}-\mathrm{f}$ & $22,85 \mathrm{~d}-\mathrm{f}$ & $18,66 \mathrm{fg}$ & $27,83 \mathrm{~b}-\mathrm{d}$ & 26,45 b-e & $22,66 \mathrm{~b}$ \\
\hline 30 & $18,79 \mathrm{fg}$ & $28,07 \mathrm{~b}-\mathrm{d}$ & $30,34 \mathrm{~b}$ & $19,01 \mathrm{fg}$ & $35,74 \mathrm{a}$ & $28,56 \mathrm{bc}$ & $26,75 \mathrm{a}$ \\
\hline Rerata & $18,01 \mathrm{c}$ & $24,61 \mathrm{~b}$ & $24,76 \mathrm{~b}$ & $18,87 \mathrm{c}$ & $29,06 \mathrm{a}$ & $25,80 \mathrm{~b}$ & \\
\hline
\end{tabular}

KK : 7,44\% $\quad$ BNJ KF : 5,36 $\quad$ BNJ K : $1,42 \quad$ BNJ F : 2,48

Angka-angka pada baris dan kolom yang diikuti huruf kecil yang sama menunjukan tidak berbeda nyata menurut uji lanjut BNJ pada taraf $5 \%$.

Data pada Tabel 4 dapat dilihat bahwa pemberian kompos serasah jagung sebanyak 30 ton/ha dan frekuensi pemupukan NPK 2 kali dengan dosis $300 \mathrm{~kg} / \mathrm{ha}$ yang diberikan setengah dosis pada saat tanam dan setengahnya lagi 2 minggu setelah tanam menunjukkan hasil terbaik dibandingkan perlakuan lainnya.

Penggunaan kompos dapat meningkatkan pertumbuhan dan meningkatkan produksi umbi bawang merah. Hal ini karena dipengaruhi oleh unsur hara yang terkandung dalam kompos. Dalam perkembangan buah, unsur yang paling penting adalah unsur N, P dan K. Menurut Shanchez (1992), tanaman umbi-umbian organik mempunyai kandungan hara makro $\mathrm{N}$, $\mathrm{P}$ dan $\mathrm{K}$ yang rendah tetapi mengandung hara mikro dalam jumlah cukup yang sangat diperlukan dalam pertumbuhan tanaman.

NPK yang diberikan terbaik pada dosis $300 \mathrm{~kg} / \mathrm{ha}$ dengan 2 kali pemberian.Pemberian pertama pada saat tanam setengah dosisnya (150 $\mathrm{kg} / \mathrm{ha}$ ) dan setengah dosis lagi bisa diberikan pada tanaman umur 2 atau 3 minggu setelah tanam.Ini lebih baik dari pada diberikan sekaligus pada saat tanam. Hal ini mungkin dikarenakan pada saat tanam diberikan untuk pertumbuhan tunas dan jumlah daun/anakan, sedangkan diberikan 2 atau 3 minggu setelah 
Aplikasi Pupuk Kompos dan Frekuensi Pemupukan NPK dalam Meningkatkan Produksi Bawang Merah (Allium ascalonicum L) pada Tanah Gambut

tanam untuk pembentukan dan pembesaran umbi bawang merah.

\section{Berat Umbi Kering Per Rumpun}

Hasil pengamatan terhadap parameter pengamatan berat umbi kering per rumpun bawang merah pada tanah gambut setelah dianalisis ragam menunjukkan bahwa pengaruh interaksi dan utama aplikasi pupuk kompos dan frekuensi pemupukan NPK nyata.Rerata Berat umbi kering per rumpun dapat dilihat pada Tabel 5. perlakuannya sehingga belum dapat mencapai hasil rata-rata atau maksimal.

Hasil penelitian Sinaga, E.M dkk (2013) menyatakan bahwa penyebab suatu varietas beradaptasi dengan baik, yaitu varietas terdiri dari satu macam genotif yang mempunyai susunan genetik sedemikian rupa sehingga mampu mengendalikan sifat morfologi dan fisiologi yang dapat menyesuaikan diri pada lingkungan dan varietas terdiri dari sejumlah genotif yang berbeda, masing-masing mampu menyesuaikan diri terhadap perbedaan kisaran

Tabel 5. Rerata berat kering umbi per rumpun bawang merah dengan perlakuan kompos serasah jagung dan frekuensi pemupukan NPK pada tanah gambut $(\mathrm{g})$

\begin{tabular}{cccccccc}
\hline \multirow{2}{*}{$\begin{array}{c}\text { Kompos } \\
\text { (ton/ha) }\end{array}$} & \multicolumn{6}{c}{ Frekuensi Pemupukan NPK (kali/kg/ha) } & \multirow{2}{*}{ Rerata } \\
\cline { 2 - 6 } & $1 / 150$ & $1 / 300$ & $1 / 450$ & $2 / 150$ & $2 / 300$ & $2 / 450$ & \\
\hline 10 & $15,04 \mathrm{fg}$ & $18,80 \mathrm{~d}-\mathrm{f}$ & $17,53 \mathrm{e}-\mathrm{g}$ & $15,21 \mathrm{fg}$ & $19,21 \mathrm{c}-\mathrm{f}$ & $18,71 \mathrm{~d}-\mathrm{f}$ & $17,42 \mathrm{~b}$ \\
20 & $12,93 \mathrm{~g}$ & $19,53 \mathrm{c}-\mathrm{f}$ & $19,00 \mathrm{~d}-\mathrm{f}$ & $15,11 \mathrm{fg}$ & $23,93 \mathrm{~b}-\mathrm{d}$ & $22,39 \mathrm{~b}-\mathrm{e}$ & $18,81 \mathrm{~b}$ \\
30 & $15,09 \mathrm{fg}$ & $23,66 \mathrm{~b}-\mathrm{d}$ & $26,09 \mathrm{~b}$ & $15,14 \mathrm{fg}$ & $31,93 \mathrm{a}$ & $24,56 \mathrm{bc}$ & $22,74 \mathrm{a}$ \\
Rerata & $14,35 \mathrm{c}$ & $20,66 \mathrm{~b}$ & $20,87 \mathrm{~b}$ & $15,15 \mathrm{c}$ & $25,02 \mathrm{a}$ & $21,89 \mathrm{~b}$ & \\
\hline
\end{tabular}

KK : 9,11\% BNJ KF : $5,48 \quad$ BNJ K : $1,45 \quad$ BNJ F : 2,54

Angka-angka pada baris dan kolom yang diikuti huruf kecil yang sama menunjukan tidak berbeda nyata menurut uji lanjut BNJ pada taraf $5 \%$.

Data pada Tabel 5 dapat dilihat bahwa aplikasi pupuk kompos dosis 30 ton/ha dan frekuensi pemupukan 2 kali dengan dosis 300 $\mathrm{kg} / \mathrm{ha}$ sudah mampu meningkatkan berat kering bawang merah sebesar 31,93 g. Hal ini menunjukkan bahwa bawang merah yang dibudidayakan di tanah top soil juga bisa beradaptasi pada tanah gambut asalkan pemupukan dilakukan secara maksimal sesuai yang diinginkan untuk budidaya di tanah gambut dan juga tidak terlepas dari peran akar yang berfungsi untuk proses penyerapan zat-zat dari dalam tanah untuk ditransportasikan ke seluruh tubuh sehingga menghasilkan berat tanaman bawang merah yang meningkat pula. Pertambahan berat dipengaruhi oleh adanya proses pemanjangan sel yang diikuti oleh pembesaran sel.

Jika dibandingkan dari penelitian sebelumnya (Sutriana dan Raisa, 2017) yaitu $35,67 \mathrm{~g}$ memang yang dihasilkan ini tergolong rendah yaitu 31,93, dan dibandingkan dengan hasil penelitian Sutriana dan Herman (2014) menjelaskan bahwa pada media tumbuh gambut mampu menghasilkan berat umbi per rumpun 53,60 g. Hal ini mungkin dikarenakan gambut yang digunakan belum maksimal diberi lingkungannya.

Ketersediaan unsur hara (N, P, K) yang terkandung dalam kompos, memberikan respon yang positif terhadap pertumbuhan umbi, yang akan diserap dan ditranslokasikan ke daun untuk diasimilasikan dalam proses fotosintesis. Salah satu hasil fotosintesis ini adalah fruktan, dimana fruktan sangat diperlukan untuk pembentukan umbi (Yetti dan Elitta, 2008). Tanaman Liliaceae menyimpan fruktan di dalam umbi (Salisbury dan Ross, 1995). Sartono (2010) menyatakan faktor yang mempengaruhi perbedaan pertumbuhan hingga produksi bawang merah selain faktor eksternal juga faktor internal yaitu genetik.

\section{Persentase Susut Umbi}

Hasil pengamatan terhadap parameter pengamatan persentase susut umbi bawang merah pada tanah gambut setelah dianalisis ragam menunjukkan bahwa pengaruh interaksi dan utama aplikasi pupuk kompos dan frekuensi pemupukan NPK nyata.Rerata persentase susut umbi dapat dilihat pada Tabel 6 .

Data pada Tabel 6 dapat dilihat bahwa persentase susut umbi kecil atau sama dengan deksripsi bawang merah yaitu rata-rata $17 \%$, sedangkan dideskripsi 22\%. Menurut Soedomo 
Tabel 6. Rerata persentase susut umbi bawang merah dengan perlakuan kompos serasah jagung dan frekuensi pemupukan NPK pada tanah gambut (hst)

\begin{tabular}{cccccccc}
\hline \multirow{2}{*}{$\begin{array}{c}\text { Kompos } \\
\text { ton/ha) }\end{array}$} & \multicolumn{6}{c}{ Frekuensi Pemupukan NPK (kali/kg/ha) } & \multirow{2}{*}{ Rerata } \\
\cline { 2 - 6 } & $1 / 150$ & $1 / 300$ & $1 / 450$ & $2 / 150$ & $2 / 300$ & $2 / 450$ & \\
\hline 10 & $18,43 \mathrm{~b}-\mathrm{d}$ & $15,97 \mathrm{a}-\mathrm{c}$ & $16,93 \mathrm{a}-\mathrm{d}$ & $19,89 \mathrm{~b}-\mathrm{d}$ & $18,61 \mathrm{~b}-\mathrm{d}$ & $16,50 \mathrm{a}-\mathrm{c}$ & $17,72 \mathrm{~b}$ \\
20 & $23,12 \mathrm{~d}$ & $16,57 \mathrm{a}-\mathrm{c}$ & $16,86 \mathrm{a}-\mathrm{c}$ & $19,06 \mathrm{~b}-\mathrm{d}$ & $14,08 \mathrm{ab}$ & $15,41 \mathrm{a}-\mathrm{c}$ & $17,51 \mathrm{~b}$ \\
30 & $19,77 \mathrm{~b}-\mathrm{d}$ & $15,77 \mathrm{a}-\mathrm{c}$ & $14,00 \mathrm{ab}$ & $20,34 \mathrm{~cd}$ & $10,76 \mathrm{a}$ & $13,98 \mathrm{ab}$ & $15,77 \mathrm{a}$ \\
Rerata & $20,44 \mathrm{~b}$ & $16,10 \mathrm{a}$ & $15,93 \mathrm{a}$ & $19,76 \mathrm{~b}$ & $14,48 \mathrm{a}$ & $15,29 \mathrm{a}$ & \\
\hline
\end{tabular}

KK : $11,95 \quad$ BNJ KF : $6,22 \quad$ BNJ K : $1,65 \quad$ BNJ F : 2,88

Angka-angka pada baris dan kolom yang diikuti huruf kecil yang sama menunjukan tidak berbeda nyata menurut uji lanjut BNJ pada taraf 5\%.

(2006), menyatakan penyusutan umbi bawang merah setelah penyimpanan umumnya $5-30 \%$. Bawang merah yang memiliki penyusutan umbi terendah memiliki daya simpan yang baik serta tidak mudah busuk dan berkecambah selama proses penyimpanan. Bawang merah memiliki masa simpan yang lebih panjang karena memiliki kandungan air dalam umbi yang idea, kekerasan tekstur serta jumlah padatan terlarut pada varietas bawang merah merupakan hal yang mempengaruhi penyusutan umbi saat penyimpanan dan kualitas simpan bawang merah.

Menurut Mutia, A.K, dkk (2014), menyatakan bahwa susut bobot umbi selama penyimpanan merupakan parameter mutu/kualitas yang mencerminkan tingkat kesegaran. Semakin tinggi susut umbi maka semakin kurang tingkat kesegarannya. Bila susut umbi semakin rendah maka menunjukkan mutu/kualitas umbi tersebut baik serta masa simpan umbi akan lebih lama.

\section{KESIMPULAN}

Gambut sebelum dan sesudah diberi perlakuan memberikan hasil yang tidak

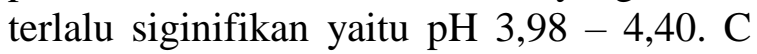
organic 42,85 - 21,14. N-total 0,30-0,47. P2O5 42,42 - 18,45. KTK 50,68 - 67,31. Pengaruh interaksi dan utama aplikasi pupuk kompos dan frekuensi pemupukan NPK nyataterhadap semua parameter pengamatan dengan perlakuan terbaik kompos 30 ton/ha dan 2 kali pemupukan dosis $150 \mathrm{~kg} / \mathrm{ha}$ per sekali beri (300 kg/ha).

\section{UCAPAN TERIMA KASIH}

Ucapan terima kasih disampaikan kepada Direktorat Riset dan Pengabdian
Masyarakat Direktorat Jenderal Penguatan Riset dan pengembangan Kementerian Rieset, Teknologi dan Pendidikan Tinggi yang telah mendanai penelitian ini tahun 2018 dalam skema Penelitian Dosen Pemula, Rektor Universitas Islam Riau, Ketua Lembaga Penelitian dan Pengabdian Masyarakat Universitas Islam Riau, Dekan Fakultas Pertanian dan rekan-rekan dosen serta mahasiswa Agroteknologi semester 5 dan 7 yang telah membantu dalam penelitian ini.

\section{DAFTAR PUSTAKA}

Agus Aryanti, E, Yulita, Rani, A dan Annisava 2016. Pemberian beberapa amelioran terhadap perubahan sifat kimia tanah gambut. Jurnal Agroteknologi. 7 (1):1926.

Bancin, RR, Murniati dan Idwar. 2016. Pertumbuhan dan produksi bawang merah (Allium ascalonicum L.) di lahan gambut yang diberi amelioran dan pupuk nitrogen. Jom Faperta, Universitas Riau 3 (1):1-12.

Firmansyah, M.A., Musaddad, D., Liana, T., Mokhtar, M.S., dan Yufdi, M.P. 2014. Adaptasi Bawang Merah di Lahan Gambut Pada Saat Musim Hujan di Kalimantan Tengah. Jurnal Hortikultura 24(2):114123

Jaelani. 2007. Khasiat Bawang Merah. Kanisius, Yogyakarta.

Jumin. 2012. Dasar - dasar Agronomi. Rajawali Pers. Jakarta.

Kusmana, Basuki, R dan Kurniawan, H. 2009. Uji adaptasi lima varietas bawang merah asal dataran tinggi dan medium pada ekosistem dataran rendah Brebes. Jurnal Hortikultura 19 (3): 281-286. 
Lingga, P dan Marsono. 2007. Petunjuk Penggunaan Pupuk NPK 16:16:16. PT Penebar Swadaya. Jakarta.

M. Syakir, M.H. Bintoro,dan H. Agusta. 2009. Pengaruh ampas sagu dan kompos terhadap produktivitas lada perdu. Jurnal Littri, 15(4): 168 - 173.

Maryati, Nelvia dan Anom, E 2014. Perubahan sifat kimia tanah sawah saat serapan hara maksimum oleh padi (Oryza sativa L.) setelah aplikasi campuran kompos tandan kosong kelapa sawit (TKKS) dengan abu boiler', Jom Faperta, vol. 1, no. 2, hlm. 114.

Masganti, Subiksa, IGM, Nurhayati dan Syafitri, W. 2014. 'Respon tanaman tumpangsari (kelapa sawit+nenas) terhadap ameliorasi dan pemupukan di lahan gambut terdegradasi', in Prosiding Seminar Nasional Pengelolaan Berkelanjutan Lahan Gambut Terdegradasi untuk Mitigasi Emisi GRK dan Peningkatan Nilai Ekonomi., Badan Penelitian dan Pengembangan Pertanian. Kementerian Pertanian, hlm. 117-132.

Puspita, F., Hasman dan Hapsoh. 2017. Pertumbuhan dan produksi Bawang Merah (Allium ascalonicum L.) dengan Pemberian Trichokompos Jerami Padi dan Kalium di Lahan Gambut. Jurnal Penelitian Fakultas Pertanian Universitas Riau. 4(1) : 1-15.

Putrasamedja, S .2010. Perbaikan varietas bawang merah (Allium ascallonicum $\mathrm{L}$ ) melalui persilangan. Jurnal Agritek12 (1); $1-10$.
Salisbury, FB \& Ross, CW 1995, Fisiologi Tumbuhan, ITB, Bandung., F., dan I.G. Subiksa. 2008. Lahan gambut: potensi untuk pertanian dan aspek lingkungan. Balai Penelitian Tanah. Badan Litbang Pertanian. World Agroforestry Centre. Bogor

Sanchez, P. 1992, Sifat dan Pengelolaan Tanah Tropika, ITB, Bandung.

Setyorini, D., R. Saraswati, dan E.K.K. Anwar. 2006. Kompos. Hlm 11-40 dalam R.D.M. Simanungkalit, D.A. Suriadikarta, R. Saraswati, D. Setyorini, dan W. Hartatik (Eds.). Pupuk Organik dan Pupuk Hayati. Balai Besar Litbang Sumberdaya Lahan Pertanian. Bogor.

Sinaga, EM, Bayu, ES \& Nuriadi, I 2013, 'Adaptasi beberapa varietas bawang merah (Allium ascalonicum L.) di dataran rendah Medan', Jurnal OnlineAgroekoteknologi,1 (3); 404-417.

Sutriana, S \& Herman 2014, 'Uji tiga varietas dan media tumbuh terhadap pertumbuhan dan produksi bawang merah (Allium ascalonicum L.)', dalamProsiding Seminar Nasional Agribisnis Universitas Islam Riau Pekanbaru.

Sutriana, S. dan Raisa. 2017. Uji tingkat kematangan kompos terhadap tiga varietas bawang merah pada tanah gambut. Laporan Penelitian Dosen Pemula Dikti.

Yetti, H. dan Elita, E. 2008, 'Penggunaan pupuk organik dan $\mathrm{KCl}$ pada tanaman bawang merah (Allium ascalonicum L.)', Jurnal Sagu, 7 (1); 13-18. 
